\title{
Korupsi, Kolusi dan Nepotisme (KKN) dalam Perspektii Hadis
}

\author{
Hasbi Sidik \\ Dosen Sekolah Tinggi Agama Islam Negeri Sorong Papua Barat \\ jalanbima762@gmail.com
}

Abstract: Corruption is a social phenomenon has existed since the era of the history of Egyptian, Babylonian, Hebrew, Indian, Chinese, Greek, and Ancient Rome. Corruption on the surface appear as a problem. From start to tarap simple to the very modern. Various efforts have been made, law enforcement officials made various efforts to be able to cope. But along with the development of time corruption growing. Including Indonesia Corruption in our country and the day rather than getting lost, it became increasingly greater amounts and fantastic, with the number of players who more and more and congregation. Where did it from starting low-level employees to senior officials, civilian and military officials. This is an emergency that must be taken seriously. Because corruption is so diverse. If not immediately anticipated it will take effect very broad. Corruption occurs in almost all of developing countries including Indonesia besides Nigeria, Peru and the Philippines. A new issue currently developing is that corruption is related to the other organized crimes especially to the attempt of corruptors to hide their corruption-originated income through money laundering by using derivative transaction through an effective international transfer. Meanwhile, according to the data found by Asian Development Bank in Perceived Standard, it is stated that Indonesia belongs to the first place in cost competitiveness if com- 
pared to the other Asian countries. One of the ways which can be used by the Government of Indonesia is to confiscate the assets of the corruptors by claiming the assets obtained through a criminal act by means of what is called civil forfeiture in the countries practicing common law. Civil forfeiture was originally from England which was then developed in the United States which also practices the Principle of Common Law. This article describe about the corruption in the hadis maudu', the classic are of Islam.

Keywords: Corruption, History of Hadis Maudu' and Social Justice

\section{Pendahuluan}

Salah satu isu krusial dewasa ini yang menjadi perbincangan publik adalah masalah korupsi, kolusi dan nepotisme (KKN). Masalah ini merupakan persoalan moral dan budaya yang tumbuh dan berkembang di hampir semua sistem birokrasi suatu lembaga, baik sosial, ekonomi, lebih-lebih politik. Korupsi, kolusi dan nepotisme (KKN) disebut dalam satu napas kerena ketiganya melanggar kaidah kejujuran, melanggar hukum yang berlaku, menurunkan kewibawaan negara dan pemerintah, lagi pula mengakibatkan high cost economy yang menaikkan harga produk dan menurunkan daya saing. ${ }^{1}$ Semua demi keuntungan untuk memperkaya diri pribadi dan atau keluarga. Akibatnya, timbul kesenjangan ekonomi dan sosial antara golongan kaya raya dan berkuasa di level atas, dan golongan wong cilik yang sehari-hari harus bekerja keras untuk mempertahankan hidup yang layak di level bawah.

Oleh karena itu, dari aspek normatif, jelas bahwa KKN diharamkan oleh agama. ${ }^{2}$ Larangan KKN sebagaimana dipahami dari ajaran tersebut menunjukkan bahwa KKN melanggar hukum, tidak bermoral, berlaku aniaya dalam arti merugikan pihak lain. Di samping itu, perlu

1 Robert Klitgaard, Controlling Corruption, diterjemahkan oleh Hermoyo dengan judul Membasmi Korupsi, Ed. 2 (Cet. II: Jakarta Yayasan Obor Indonesia, 2001), h. xiii

2 Lihat misalnya QS. 4: 29-30; QS. 5: 2 dan juga dalam berbagai hadis Nabi saw yang menyangkut KKN. 
digaris bawahi bahwa tujuan penetapan hukum dalam Islam, termasuk larangan $\mathrm{KKN}$, adalah untuk memelihara kemaslahatan manusia sekaligus menghindari mafsadat. ${ }^{3}$

Berpijak pada uraian di atas, maka yang menjadi fokus permasalahan pada makalah ini, yaitu bagaimana dasar hukum larangan KKN dalam perspektif hadis Nabi saw.

\section{Konsep Korupsi, Kolusi dan Nepotisme [KKN]}

Dalam Kamus Besar Bahasa Indonesia disebutkan bahwa korupsi berarti penyelewengan atau penyalahgunaan uang negara (perusahaan dan sebagainya) untuk keuntungan pribadi atau orang lain. Korup berarti suka memakai barang (uang) yang dipercayakan kepadanya; dapat disogok (memakai kekuasaan hanya untuk kepentingan pribadi. ${ }^{4}$ Sedangkan kolusi berarti kerjasama rahasia untuk maksud tidak terpuji. ${ }^{5}$ Adapun nepotisme berarti kecenderungan untuk mengutamakan (menguntungkan) sanak saudara sendiri, terutama dijabatan, pangkat di lingkungan pemerintah. ${ }^{6}$ Penggunaan pengertian korupsi, kolusi dan nepotisme yang telah dikemukakan di atas, kemudian berkembang, sehingga dewasa ini KKN berlaku untuk setiap praktek favoritisme, khususnya dalam birokrasi pemerintahan.

\section{Takhrij Hadis-Hadis Korupsi}

Takhrij al-hadis adalah kegiatan pencarian hadis sampai mene-

3 Lihat Fathi al-darainiy, al-Manhaj al-Ushuliyah fiy al-Ijtihad bi Ra'yi fi al-Tasyri' (Damysiq: Dar al-Kitab al-Hadis, 1975), h. 28. Muhammad Abu Zahrah, Ushul al-Fiqh (Mesir: Dar al-Fikr al-Arabiy, 1985), h. 366.

4 Departemen Pendidikan dan Kebudayaan, Kamus Besar Bahasa Indonesia (Jakarta: Balai Pustaka, 2000), h. 597

5 Ibid., h. 582

6 Ibid., h. 780

7 Term takhrīj berakar kata dari kharraja yang memiliki sinonim dengan kata al-istimbät (mengeluarkan), al-tadrīb (meneliti) dan al-tawjīh (menerangkan). Muhammad Mahmud al-Thahhān, Ushul Takhrīj al-Hadīś a-Nabawiy (Cet. I; Mesir: 
mukannya dalam berbagai kitab hadis yang disusun langsung oleh mukharrij-nya, di mana dalam kitab-kitab tersebut disebutkan hadis secara lengkap dari segi sanad dan matan. ${ }^{8}$ Kaitannya dengan itu dan untuk mencari hadis-hadis tentang KKN, maka penulis melakukan kegiatan takhrij al-hadis melalui alat bantu berupa Mu'jam al-Mufahras li Alfaz al-Hadis al-Nabawiyah. Takhrīj hadis dilakukan dengan menggunakan lafal هدي dan melalui lafal ini, maka Mu’jam memberikan petunjuk sebagai berikut :

$$
\begin{aligned}
& \text { هذا لكم وهذا اهدى للى ... يهدى له ام لا ... } \\
& \text { خ : هبة 7، النذور } 12 \text {. م : احكام، 41، امارة } 28 \\
& \text { د : إمارة 8.** دى : زكاة 17، السير } 7 \\
& \text { ن: بيوع 22. حم : 5، } 211
\end{aligned}
$$

Berdasarkan petunjuk Mu'jam hadis di atas, maka diketahui hadis tentang korupsi terdapat dalam kitab-kitab rujukan hadis sebagai berikut:

1. Shahīh al-Bukhāri, kitāb al-Hibah, bab 7 dan kitāb al-Nuzūr, bab 12

2. Shahīh Muslim, kitāb Ahkām, bab 41 dan kitāb Imārah, bab 28

3. Sunan Abū Dāwud, kitāb Imarah, bab 8 terdapat dua matan hadis.

Dikatakan bahwa dalam bab ini terdapat dua matan hadis, karena Mu'jam memberikan petunjuk ** (tanda dua bintang).

4. Sunan al-Dārimiy, kitāb Zakat, bab 17 dan Kitāb al-Sayr, bab 7

\footnotetext{
Bab al-Halab wa Awladuht.th), h. 43

8 M. Syuhudi Ismail, Metodologi Penelitian Hadis (Cet. II; Jakarta: Bulan Bintang, 1992), h. 62.

9 Arnold John Wensinck, et al, Concordance et Indices De Ela Tradition Musulmanne, diterjemahkan ke dalam bahasa Arab oleh Muhammad Fu'ad 'Abd. al-Bāqy dengan judul al-Mu’jam al-Mufahras Li Alfaz al-Hadīś al-Nabawy, jilid VII (Leiden: E.J.Brill, 1936), h. 78-79
} 
5. Sunan al-Nasai, kitāb Buyü', bab 22

6. Musnad Ahmad bin Hanbal, juz 5 halaman 211.

Berdasarkan pengertian korupsi di atas, yaitu penyalahgunaan kekuasaan atau jabatan, maka hadis yang dapat dikategorikan hadis korupsi adalah hadis mengenai hadiah bagi pejabat dalam melaksanakan tugas. Berikut ini, akan dikutip tiga hadis yang terkait dengan masalah tersebut. Dua hadis yang dimaksud adalah 1 hadis riwayat al-Bukhāri dan 2 hadis riwayat Abū Dāwud

1. Susunan sanad dan matan hadis riwayat al-Bukhāri;

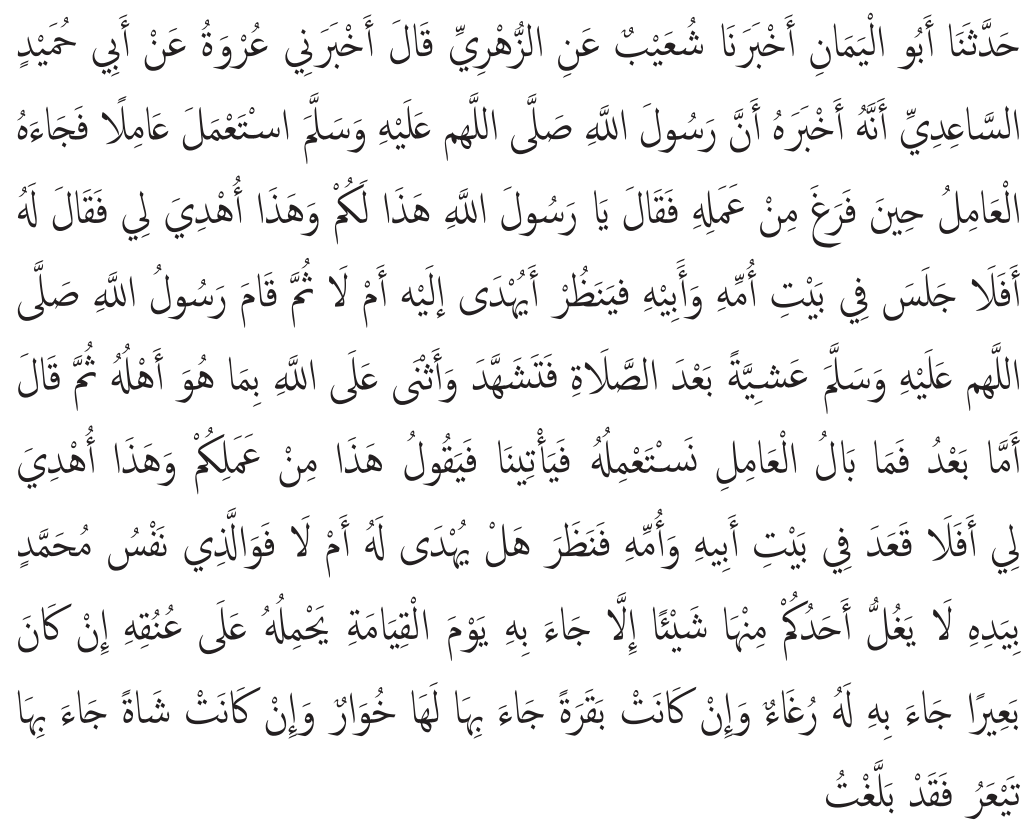

Artinya :

Abu al-Yaman telah memberitakan kepada kami, berkata: Syua'ib telah memberitakan kepada kami, berkata: darial-Zuhri, berkata; 'Urwah telah mmberitakan kepada kami, berkata; dari Humaid al-Saidiy bahwa Rasulullah mengangkat seorang pejebat pengumpul zakat (amil). Ketika pejabat telah selesai melaksanakan tugasnya, dia datang kepada Nabi dan berkata: "Ya Rasulullah, ini untuk anda dan ini hadia yang diberikan orang kepada saya", maka Nabi saw bersabda kepada pejabat 
itu: "mengapa kamu tidak duduk saja di rumah ayah atau ibumu sehingga kamu dapat melihat apakah dengan kamu juga akan memperoleh hadiah atau tidak ?" kemudian pada waktu petang sesudah shalat Nabi saw berdiri (berpidato di hadapan orang banyak). Sesudah membaca kalimat syahadat dan memuji Allah dengan pujian yang Dialah sebagai pemilik pujian itu, Nabi mengatakan." Adapun sesudah itu, bagaimanakah halnya bila seorang pejabat yang kami serahi tugas lalu dia datang melapor kepada kami seraya berkata: "ini adalah hasil tugas yang berasal dari anda. Sedangkan ini adalah (bagian) yang dihadiahkan kepada saya, "mengapa dia tidak duduk saja di rumah ayah atau ibunya, sehingga ia dapat melihat apakah ia akan diberi hadiah (oleh orang) atau tidak. Demi Allah yang diri Muhammad berada dalam genggaman-Nya tiadalah seseorang dari kalian melakukan sesuatu pengkhianatan, kecuali nanti pada hari kiamat dia akan memikul beban dilehernya. Jika (yang dikorupsi) adalah seekor unta, maka dia datang dengan suara unta. Jika yang dikorupsi adalah seekor sapi, maka orang itu akan datang dengen melenguh seperti sapi; bila (yang dikorupsi) adalah seekor kambing, maka orang itu akan datang dengen mengembek. Sungguh (hal itu) telah kusampaikan kepada kalian.

2. Susunan sanad dan matan hadis riwayat Abū Dāwud;

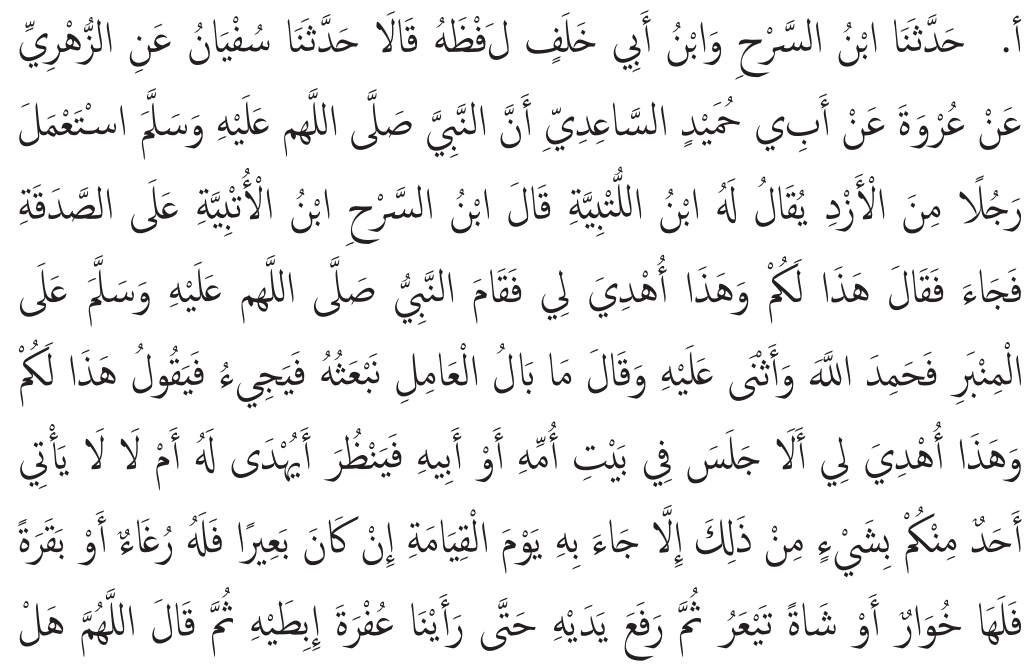




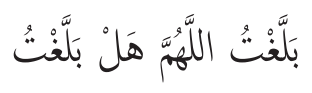

Artinya :

Ibn al-sarāh dan Ibn Abī Khalaf telah memberitakan kepada kami, dengan lafaznya ia berkata: Sufyān memberitakan kepada kami, dari al-Zuhri, dari 'Urwah, dari Abī Humaid al-Sä'idy bahwa Nabi saw telah mempekerjakan seorang lakilaki dari suku Azdi dan dinamakannya Ibn Lutbiyah. Ibn Sarāh berkata: (bahwa ia adalah) Ibn Utbiyah (ia mempekerjakan) dalam urusan sedekah maka ia datang (menghadap kepada Nabi saw seusai melaksanakan tugasnya): ini (bagin) untuk kamu dan ini (bagian) yang dihadiahkan kepadakau. Maka mendengar hal itu Nabi saw bangkit ke mimbar dan memuji Allah swt dan mempersembahkan pujian kepadanya dan bersabda: tidak beruntung seseorang pekerja yang telah dimandatir kepadanya, lalu ia datang (seusai melaksanakan tugasnya) dan berkata: ini (bagian) untuk kamu sekalian dari sesuatu (yang dihadiahkan itu) pada hari kiamat, kecuali ia datang bersamanya (hadiah yang diterimanya itu) dan jiak unta maka ia berauara unta atau sapi maka ia bersuara sapi atau kambing maka ia bersuara kambing, kemudian Nabi saw mengangkat kedua tangannya sehingga kami melihat putihnya ketiaknya dan bersabda: Ya Allah apakah telah kusampaikan ya Allah, apakah telah kusampaikan.

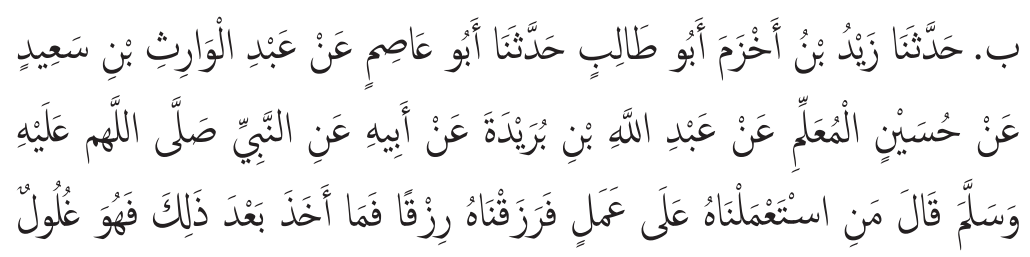

Artinya:

Zaid bin Akhzam Abū Thālib memberitakan kepada kami, dari Abū Ashim, dari Abdul Waris bin Sa'ìd dan Husain al-Muallim, dari Abdullah bin Buraidaj dari Bapaknya, dari Nabi saw bersabda: Barang siapa yang dipekerjakan dalam suatu pekerjaan dan ia diberi gaji, tetapi ia mengambil (gaji lain) setelah ia digaji (sesuai hasil kerjanya), maka ia termasuk korupsi. 
Hadis pertama dan hadis kedua yang dikutip di atas, ditemukan term uhdiyah yang secara tekstual mengandung arti "hadiah" tetapi, jika dianalisis secara kontekstual, maka dapat mengandung arti "korupsi”. Sedangkan hadis yang ketiga, terdapat term ghulül, yang secara tektstual dan kontekstualnya mengandung arti "korupsi". Untuk mengetahui lebih lanjut menganai kandungan hadis-hadis di atas, maka term uhdiyah dan term ghulül akan dijadikan bahan kajian. Namun sebelumnya, akan dikaji terlebih dahulu mengenai kandungan hadis-hadis tersebut berdasarkan urutan frase dan klausanya.

Hadis di atas, dimulai dengan kata استعمل yang merupakan fi'il madhi, berasal dari kata عمل Kata ini memperoleh tiga huruf tambahan pada awalnya sehingga menjadi sesuai dengan timbangan ستفعل|, yang artinya: menjadikan seseorang sebagai pekerja atau meminta melakukan sesuatu. ${ }^{10}$ Dalam hal ini, makna yang dimaksud adalah mempekerjakan.

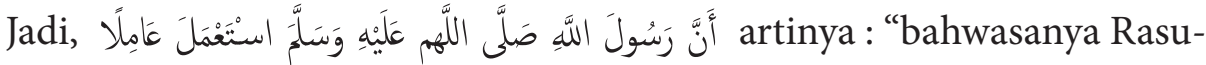
lullah saw mempekerjakan seseorang sebagai amil (pengumpul zakat)”. Lalu ia datang kepada Nabi setelah tugasnya selesai.

Dalam Sunan Abū Dāwud dikatakan bahwa hadis tersebut di atas terkait dengan masalah korupsi, karena ia termpatkan pada bāb ghulūl. Dijelaskan lebih lanjut bahwa lafaz هدي dalam hadis menunjukkan bahwa pihak pelaksana tugas atau pegawai yang menyatakan "ini hadiah bagiku" secara tekstual tidak diketahui siapa yang memberi hadiah. Karena itu, boleh jadi pemberi hadiah yang tersembunyi itu (mabniy majhul) itu bersumber dari pengambilan koruptur dari zakat yang dikumpul atau terdapat seorang yang memberikan hadiah. Jadi di sini terjadi kesan negatif tentang masalah pemberian hadiah dan menerima hadiah tersebut, karena ia diidentikkan dengan korupsi. Dikatakan demikian, karena di sini terlihat bahwa hadiah yang diberikan oleh pemberi hadiah kepada pejabat yang melaksanakan tugas dilihat dari sisi waktu pemberiannya kurang tepat, seharusnya hadiah yang diberikan itu, diserahkan pada saat selesai melaksanakan tugas dan jauh

\footnotetext{
${ }^{10}$ Louis Ma'luf, Al-Munjid fi al-Lughah, jilid I (Cet. XXXII; Bairut: Dar al-Masyriq, 1992), h. 530
} 
lebih baik jika sekiranya disampaikan kepada atasan. ${ }^{11}$

Berdasarkan keterangan di atas, maka dapat dipahami bahwa seseorang yang telah bekerja kemudian ia gaji, dan ia mengambil lagi upah selain dari gajinya itu, maka termasuklah ia sebagai koroptur. Hal ini, secara tegas disebutkan dalam hadis yang semakna yang diriwayatkan oleh Abū Dawud, yakni: Jadi kelihatannya terdapat perbedaan pengertuan antara term uhdiyah dan term ghulül. "Hadiah" menurut Kamus Besar Bahasa Indonesia adalah pemberian yang berupa kenangkenangan, penghargaan, penghormatan, atau ganjaran karena memenangkan perlombaan atau tanda mata. ${ }^{12}$ Sedangkan menurut al-Ta'rifat, hadiah ialah sesuatu yang diberikan tanpa disyaratkan mengembalikannya. ${ }^{13}$ Dari pengertian ini dapat dipahami bahwa hadiah ialah pemberian sesuatu kepada seseorang sebagai kenang-kenangan, penghargaan, penghormatan yang tidak dituntut pengembaliannya.

Sedangkan ghulūl yang berasal dari kata ghalla mengandung arti menusuk, dan dapat pula berarti penyakit. Arti pertama, mengandung arti fungsional sebagai suatu perbuatan yang dapat menusuk perasaan, pikiran akal sehat seseorang. Sedang arti kedua adalah berimplikasi negatif dalam aspek moral. Maksudnya, lafaz yaghullu menunjukkan bahwa melakukan korupsi adalah sebuah pengkhianatan atas amanah yang diberikan kepadanya. ${ }^{14}$

Selanjutnya, dalam matan hadis tersebut, juga diketahui bahwa Nabi saw bersabda kepada pejabat-pejabat itu, mengapa kamu tidak duduk saja di rumah bapakmu atau ibumu sehingga kamu dapat melihat, apakah dengan demikian kamu juga akan memperoleh hadiah atau tidak? Klausa ini nampaknya memberi indikasi bahwa karena jabatan yang diemban pejabat (amil) itulah sehingga ia diberi hadiah. Dengan kata

${ }^{11}$ Disadur dari Muhammad Syamsuddin al-Haq al-Azìm Abady, 'Awn al-Ma'bud Syarh Sunan Abi Dawud, juz X (Cet. II; Beirut: Dar al-Kutub Ilmiyah, 1410 H), h. 114-115

${ }^{12}$ Departemen Pendidikan dan Kebudayaan, op. cit., h. 291.

${ }^{13}$ Ali bin Muhammad al-Jurjani, Kitab al-Tárifat (Jeddah: al-Haramain, t.th), h. 256

${ }^{14}$ Muhammad Syamsuddin al-Haq al-Azīm Abady, loc. cit 
lain, hadiah itu tidak akan diperolehnya manakala ia bukan pejabat. ${ }^{15}$

Memahami hadis di atas, Imam Muslim secara tegas mengatakan keharaman menerima hadiah bagi seorang pejabat. Bahkan diletakkan sebagai judul bab: تحريك هدايا العمال. menurut Imam al-Nawawy, hadis ini menjelaskan bahwa hadiah bagi seorang pejabat adalah haram dan pengkhianatan. Oleh karena menerima hadiah bagi pejabat itu merupakan penyelewengan dalam kewenangan dan tanggung jawab pejabat.

Sejalan dengan itu, Ibn Hajar al-Asqalani menempatkan kedudukan hukum tahrim atas penerimaan hadiah bagi pejabat karena hal itu merupakan pengkhiatan terhadap jabatan. ${ }^{16}$ Demikian pula keterangan yang disampaikan oleh al-Hafizh Ibn Qayyim bahwa hadis ini merupakan penjelasan bahwa hadiah atas para pejabat itu adalah haram dan pengkhiatan. Oleh karena tindakan itu adalah penyelewengan terhadap kekuasaan dan tanggungjawabnya. Lebih lanjut ia mengatakan bahwa

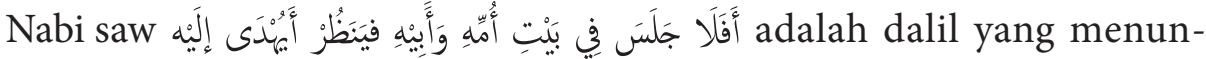
juk bahwa setiap urusan yang mengantar kepada perbuatan mudharat, maka ia pula adalah mudharat sebagaimana peminjaman barang yang membawa kepada keuntungan. ${ }^{17}$

Memperhatikan pendapat para muhaddisin di atas, dapat dipahami bahwa mereka memahami hadis ini dalam makna tekstual. Yakni memahami kandungan hadis berdasarkan teks hadis tersebut. Sehingga dapat dipahami bahwa tidak boleh seorang pejabat menerima hadiah selama ia menjalankan tugasnya, karena hadiah itu merupakan pengkhianatan dan penyelewengan dari tanggungjawab amanat yang diembangnya. Semakin besar kualias penyelewengan itu, semakin besar pula beban yang dipikulkan di lehernya pada hari kemudian.

\footnotetext{
${ }^{15}$ Imam al-Nawawi, Shahih Muslim bi Syarh al-Nawawi, jilid VI (Beirut: Dar al-Fikr, 1983), h. 219

${ }^{16}$ al-Hafidz Ibn Hajar al-Asqalani, Fath al-Bary Bi Syarh Shahih al-Bukhari, juz XV (Bairut: Dar al-Fikr, t.th), h. 68

${ }^{17}$ al-Hafidz Ibn Qayyim al-Jauziyah dan Abii al-Tayyib, op. cit., h. 115
} 
Pada sisi lain, Muhammad bin Ismail al-Kahlaniy membolehkan pemberian sesuatu kepada siapa saja yang terkait dengen kepentingan kita dalam rangka memperoleh hak kita yang sah. ${ }^{18}$ Meskipun pemberian itu tentu tidak diharapkan menimbulkan efek negatif bagi penerimanya. Misalnya, jika ia tidak diberikan sesuatu (seperti; uang pelicin), maka urusan hak itu akan tersendak-sendak.

Sejalan itu, Imam al-Syaukani seperti dikutip oleh Quraish Shihab juga membolehkan pemberian itu sepanjang pemberian itu dilakukan dengan hati yang tulus. Ia mengatakan bahwa agama pada dasarnya tidak membernarkan pemberian dan penerimaan sesuatu dari seseorang kecuali dengan hati yang tulus. ${ }^{19}$ Lebih lanjut Quraish Shihab menyatakan bahwa pemberian hadiah kepada pejabat atau aparat negara seperti keadaan yang kita alami sekarang, dapat menumbuh suburkan praktek suap menyuap dalam masyarakat. Oleh karena itu memberikan sesuatu - walau dengan dalih meraih hak yang sah sekalipun tidak boleh dikembangkan. Sebab hal itu telah membantu si penerima melakukan sesuatu yang haram dan terkutuk dalam pelaksanaan tugasnya. ${ }^{20}$ M. Quraish Sihab juga menambahkan bahwa pem-berian hadiah kepada seseorang yang berwenang - kecil ataupun besar wewenangnya - apabila sebelumnya ia tidak biasa menerimanya dinilai sebagai sogokan terselubung. ${ }^{21}$

Memperhatikan beberapa pendapat di atas, dapat ditarik benang hijau sebagai llat pengharaman pemberian hadiah kepada pejabat atau aparat negara adalah kekhawatiran timbulnya tindakan penyelewengan atas tugas-tugasnya atau perbuatan korupsi terhadap kewenangannya. Sehingga jika illat ini dapat dihilangkan, maka tentu keharaman itupun dapat berubah menjadi boleh bahkan hukumnya adalah sunnat.

\footnotetext{
${ }^{18}$ Muhammad bin Ismail al-Kahlani, Subul al-Salam, juz III (Indonesia: Maktabah Dahlan, t.th), h. 34

${ }^{19}$ M. Quraish Shihab, Lentera Hati Kisah dan Hikmah Kehidupan (Cet. XIII; Bandung, 1998), h. 297

${ }^{20}$ Ibid.

${ }^{21}$ Ibid.
} 


\section{Takhrij Hadis-hadis tentang Kolusi}

Takhrij hadis tentang kolusi, dilakukan dengan menggunakan lafal dan melalui lafal ini, maka Mu'jam memberikan petunjuk sebagai berikut:

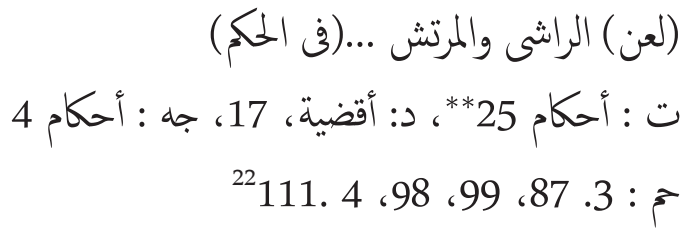

Berdasarkan petunjuk Mu'jam hadis di atas, maka diketahui hadis tentang kolusi terdapat dalam kitab-kitab rujukan hadis sebagai berikut:

1. Sunan al-Turmuzi, kitāb Ahkam, bab 25 terdapat dua matan hadis

Dikatakan bahwa dalam bab ini terdapat dua matan hadis, karena Mu'jam memberikan petunjuk ** (tanda dua bintang).

2. Sunan Abū Dāwud, kitāb Aqdiyah, bab 17

3. Sunan Ibn Mājah, kitāb Ahkam, bab 4

4. Musnad Ahmad bin Hanbal, juz 3, halaman 87, 98 dan 99; juz IV, halaman 111

Selanjutnya, kegiatan takhrīj untuk hadis-hadis tentang kolusi ini, jika ditelusuri melalui alat bantu berupa Jāmi' al-Shagīr Karya al-Suyuti, maka ditemukan petunjuk sebagai berikut :

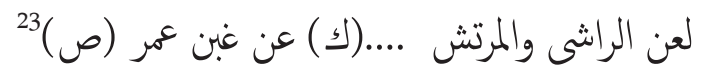

Berdasarkan petunjuk Jāmi' al-Shagìr atas, maka diketahui hadis tentang kulusi terdapat juga dalam Mustadrak al-Hākim. Hal diketahui melalui data yang diberikan dengan tanda (ك) artinya Mustadrak alHākim.

\footnotetext{
${ }^{22}$ Ibid., juz II, h. 262

${ }^{23}$ Jalāl al-Dīn Abd. al-Rahman al-Suyūtiy, Jāmi’ al-Shagìr fī Ahādīś al-Basyīr al-Nazīr jilid I; (Kairo: Dār al-Kutub al-Arab, 1967), h. 99
} 
Istilah kolusi identik dengan istilah sogok menyogok. Kolusi dapat terjadi apabila diawali dengan persekongkolan. Demikian juga, praktek sogok menyogok terjadi karena persekongkolan antara yang memberi suap dan yang menerima suap. Oleh karena itu, hadis mengenai kolusi ini penulis kaitkan dengan hadis tentang sogok menyogok disebabkan keduanya ada kemiripan dalam proses terjadinya. Istilah sogok menyogok dalam bahasa Arab disebut الراش dan المرتشى.

Berikut ini dikemukakan satu buah matan hadis dimaksud, yaitu riwayat al-Turmuzi :

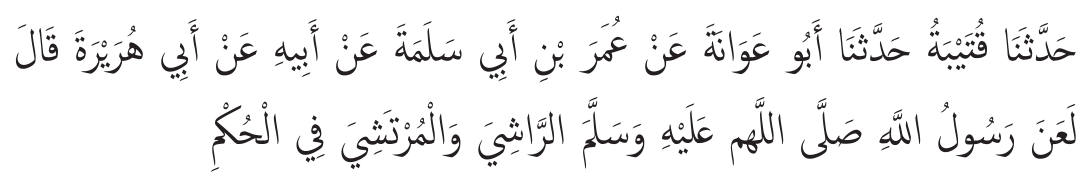

Artinya:

Qutaybah menceritakan kepada kami, berkata: Abu Awanah menberitakan kepada kami, berkata: dari Umar bin Salamah, berkata: dari bapaknya, berkata: dari Abu Huraerah, berkata: Rasululullah melaknat orang yang menyuap dan menerima suap dalam hukum pemerintahan.

Matan hadis di atas, dimulai dengan kata لعن yang berarti melaknat atau mengutuk. Kemudian, lafaz الراش berarti memberikan uang sogok, الرائش adalah orang yang menerima sogok. Sedangkan lafaz المرتشى sedang pada riwayat al-Hakim berarti orang yang menjadi perantara di antara keduanya. ${ }^{24}$ Dari kata yang terakhir disebut ini, maka dapat dipahami sogok disebut الرشوة (rasywah). Adapaun lafaz في الحكم dipahami bahwa sogok menyogok itu banyak berkaitan dengan pengambil kebijakan termasuk hakim. Dengan demikian, masalah sogok menyogok adalah erat kaitannya dengan materi berupa uang yang diberikan kepada hakim atau kepada pengambil kebijakan.

Sogok menyogok menurut teks hadis di atas, pada dasarnya adalah haram dan perbuatan yang dilaknat oleh Allah dan Rasul-Nya, tetapi

\footnotetext{
${ }^{24}$ Lihat Abu Ya'la Muhammad bin Husain al-Fara'i, Al-Ahkam al-Sultaniyah (Bairut: Dar al-Islamiyah, 1408 H), h. 83
} 
hukum dasar sogok tersebut dapat berubah menjadi boleh apabila yang menyogok itu berdalih takut dizalimi. Dengan kata lain, ia menyogok untuk mendapatkan haknya. Dengan memperhatikan hasil analisis di atas, dan dikatikan dengan maksud matan hadis, tampak terdapat perbedaan mengenai status hukum sogok menyogok. Perbedaan tersebut adalah pertama, menyebutkan bahwa orang yang menyogok dengan maksud untuk memenangkan sengketa di pengadilan yang memang bukan haknya, maka hukumnya haram. Yang kedua, menyebutkan orang yang menyogok karena takut dizalimi maka tidak apa-apa.

Dalam kitab Subul al-Salam, ${ }^{25}$ dan kitab Nail al-Awthar ${ }^{26}$ di bawah sub judul Rasywah, kedua pengarang tersebut mengemukakan pendapat yang membolehkan pemberian dalam rangka memperoleh hak yang absah. Tidak jelas argumentasi mereka, tetapi menurut M. Quraish Shihab, rupanya keadaan ketika itu mirip dengan keadaan yang kita alami sekarang ini. ${ }^{27}$ Tampaknya, ketika itu telah menjamur pula sogok menyogok, sehingga menyulitkan penuntut hak untuk memperoleh haknya, maka lahir pendapat yang membolehkan tadi. Bidang peradilan adalah bidang yang banyak dirambah oleh kasus ini. Al-San'aniy berkomentar tentang ini dengan membaginya dalam dua perspektif, yaitu hakim berlaku tidak adil dan hakim berlaku adil. Pertama, ulama ahli fiqih sependapat bahwa hukumnya haram baik bagi orang yang menerima sogokan tersebut. Kedua, yang diharamkan adalah menerima sogokan sebab berbuat adil merupakan kewajiban hakim dan keadilan adalah hak yang harus diperoleh oleh pihak yang berberperkara tanpa harus diminta. ${ }^{28}$

Selain dilarang menerima rasywah. Menurut ulama sebagaimana dikatakan lebih lanjut oleh al-San'aniy, hakim juga dilarang menerima pemberian berupa hadiah dari pihak-pihak yang berperkara, meskipun

\footnotetext{
${ }^{25}$ Muhammad Ismail al-San'aniy, Subul al-Salam, juz IV (Mesir: Maktabah al-Risalah al-Haditsah, t.th), h. 124-125

${ }^{26}$ al-Syaukani, Nail al-Awthar, juz IX (Bairut: Dar al-Fikr, t.th), h. 172-173

${ }^{27}$ M. Quraish Shihab, op. cit., h. 296

${ }^{28}$ Al-San'ani, loc. cit.
} 
pemberian itu tidak dikaitkan dengan perkara yang sedang diadilinya. Menurutnya pemberian hadiah hanya bisa diterima apabila; (1) hakim itu sebelumnya biasa menerima hadiah dari orang-orang yang memberi hadiah atas kebaikannya semata-mata, dan (2) nilai hadiah bagi hakim tersebut tidak lebih besar dari hadiah-hadiah yang biasa diterimanya. ${ }^{29}$

Dengan hukumnya adalah haram bagi pemberian rasywah maupun hadiah yang diberikan kepada hakim oleh pihak-pihak yang berperkara pada saat hakim menangani perkara mereka. Sebabnya, karena pengaruh rasywah atau hadiah, pihak-pihak yang berkompeten atau yang menentukan kebijakan dalam bidang peradilan bisa berlaku tidak adil dalam menyelesaikan urusan yang diembangnya.

\section{Takhrij Hadis-hadis Nepotisme}

Takhrij hadis tentang nepotisme, dilakukan dengan menggunakan lafal أثرة dan علثم . Melalui lafal maka Mu'jam memberikan petunjuk sebagai berikut:

$$
\begin{aligned}
& \text {... ستلقون بعدي أثرة فاصبروا ... } \\
& \text { خ : مناقب الأنصار 8، مساقة 3، جزية، } 9 \\
& \text { م : الإمارة } \\
& \text { ت : فتن } 17
\end{aligned}
$$

Sedangkan melalui lafal عمل, maka Mu'jam memberikan petunjuk sebagai berikut:

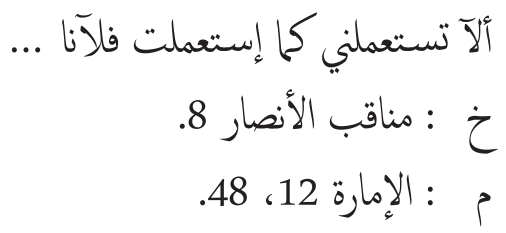

\footnotetext{
${ }^{29}$ Ibid.

${ }^{30}$ Arnold John Wensinc, op. cit., juz I; h. 14.
} 


\section{ن : تضاة 4 \\ 31.352 3 351.4}

Berdasarkan petunjuk Mu'jam hadis di atas, maka diketahui hadis tentang nepotisme terdapat dalam kitab-kitab rujukan hadis sebagai berikut :

1. Shahīh al-Bukhāri, kitab Manāqib al-Anshar bab 7; kitāb Masāqah bab 3; Kitāb Jaziyah bab 9

2. Shahīh Muslim, Kitab Imārah nomor hadis ke 12 dan 48

3. Sunan al-Turmuzi, kitāb al-Fitan, bab 17

4. Sunan al-Nasāi, kitab Qadha' bab 4

5. Musnad Ahmad bin Hanbal, juz 4, halaman 251 dan 252

Selanjutnya, kegiatan takhrij untuk hadis-hadis tentang nepotisme ini, jika ditelusuri melalui alat bantu berupa Jāmi' al-Shagìr karya alSuyuti, juga ditemukan petunjuk bahwa hadis-hadis tentang nepotisme terdapat pula dalam Mustadrak al-Hākim.

Penyelenggaran kekuasaan dengan sikap nepotisme, telah diprediksi oleh Nabi saw, sebagaimana dalam beberapa teks hadis. Berikut ini, akan dikutip dua hadis yang terkait dengan masalah tersebut. Dua hadis yang dimaksud adalah riwayat al-Bukhāri dan Turmūzi sebagai berikut:

1. Hadis riwayat al-Bukhāri

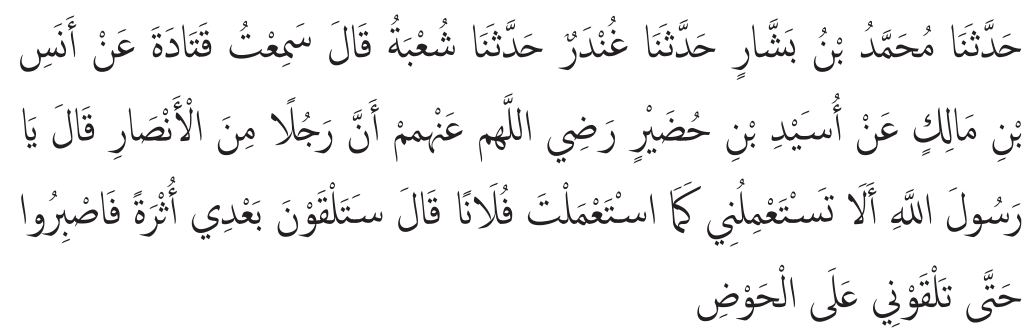

Artinya :

Muhammad bin Basysyar menceritakan kepada kami, berkata; Gundar menceritakan kepada kami, berkata: Syu'bah menceri-

\footnotetext{
${ }^{31}$ Ibid., juz IV; 379.
} 
takan kepad kami, berkata: Saya mendengar Qatadah, berkata; dari Anas bin Malik, berkata; dari Usaid bin Hudhair yang kesemuanya periwayat ini (semoga) diridhai Allah swt, berkata: bahwa seorang laki-laki dari kaum Anshar berkata: Ya Rasulullah, tidakkah engkau angkat si Fulan? Rasul menjawab : kalian akan menjumpai sepeninggalku tindakan mengutamakan kepentingan sendiri (sikap nepotisme), maka bersabarlah kalian sampai bertemu dengan ku di telaga al-kawstar (di hari kiamat).

2. Hadis riwayat al-Tumuzi

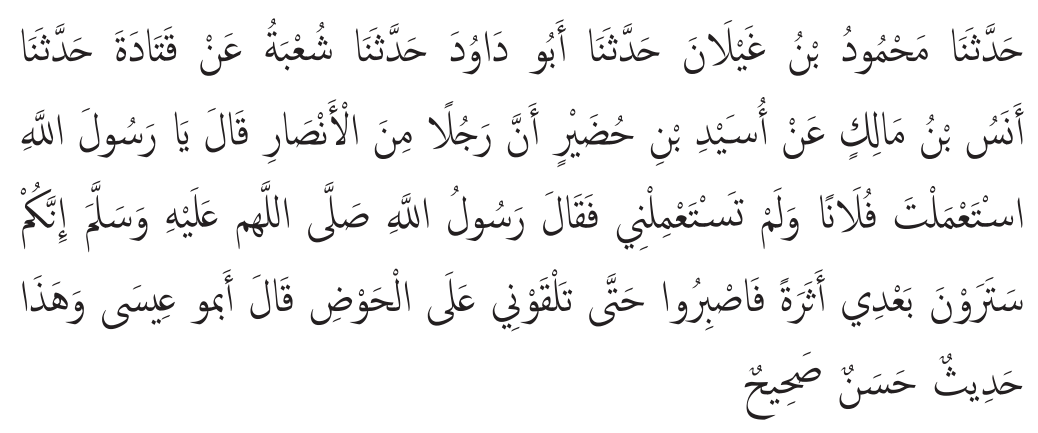

Artinya :

Mahmud bin Ghailāni menceritakan kepada kami, berkata; Abū Dāwud menceritakan kepada kami, berkata: Qatādah menceritakan kepad kami, berkata: Anas bin Malik dari Usayd bin Hudair berkata bahwa seorang laki-laki dari kaum Anshar berkata: Ya Rasulullah, tidakkah engkau angkat si Fulan? Rasul menjawab: kalian akan menjumpai sepeninggalku tindakan mengutamakan kepentingan sendiri (sikap nepotisme), maka bersabarlah kalian sampai bertemu dengan ku di telaga alkawstar (di hari kiamat).

Dua hadis yang dikutip di atas, memiliki redaksi matan yang berbeda. Hadis pertama menggunakan di pertengahan matannya menggunakan lafal سَتَلَفْوَنَ sedangkan hadis yang kedua menggunakan lafal سَنَرَوْنَ . Secara tekstual kedua lafal ini memiliki kesamaan makna. Ungkapan ألا تستعملنى merupakan pernyataan sekaligus pertanyaan Usaid bin Hudhair terhadap Rasul, yang berharap agar dia dijadikan sebagai amil 
(pegawai) yang mengurusi zakat, ataukah diangkat sebagai gubernur pada suatu daerah. ${ }^{32}$ Keinginan Usaid tersebut didasari kenyataan bahwasanya Rasul telah mengangkat orang-orang tertentu untuk tugas tersebut seperti halnya 'Amir bin Ash, sebagaimana yang dimaksudkan dari ungkapan 3.

Terhadap permintaan Usaid tersebut, secara arif Rasul menanggapinya dengan ungkapan انكم ستلقون بعد اثرة . Penulis berasumsi, jawaban Rasul tersebut dimaksudkan untuk menolak permintaan Usaid itu secara halus berdasarkan pertimbangan tertentu beliau. Tampaknya permintaan tersebut dikemukakan Usaid di hadapan orang banyak, terbukti dengan jawaban yang diberikan Rasul menggunakan frase إن dan . Dengan demikian, pernyataan tersebut tidak hanya ditujukan khusus kepada Usaid, tetapi bersifat umum.

Nabis saw secara arif dan sadar ingin menanamkan kesadaran kepada sahabatnya bahwa ada masanya nanti setelah beliau telah tiada, terjadi praktek nepotisme yang dilakukan oleh para pejabat yang diserahi amanah dan tanggung jawab terhadapnya. Mengenai kata berasal dari akar kata $ث$ yang berarti bekas dan dapat pula berarti kecenderungan. Dalam konteks hadis tersebut, menurut Abu Ubaid, أثرة berarti mementingkan diri sendiri dalam hal pembagian $f a^{\prime} i{ }^{34}$ Pengertian ini dikuatkan oleh al-Kirmaniy yang mengartikan أثرة dengan sikap penguasa yang selalu mengutamakan dirinya dan keluarganya dalam mendapatkan keuntungan duniawi. ${ }^{35}$ Dalam konteks kekinian, kecenderungan sikap seperti itu identik dengan nepotisme.

\footnotetext{
${ }^{32}$ Ibn Hajar al-Asqlani, fath al-Bariy bi Syarh Shahih al-Bukhari, juz VII (t.tp.: Dar al-Fikr wa Maktabah al-Salafiyah, t.th), h. 118

${ }^{33}$ Badr al-Din Abu Muhammad bin Ahmad al-'Ayniy, Umdah al-Qari' Syarh Shahih al-Bukhari, jilid VIII (Beirut: Muhammad Amin Damaj, t.th), h. 262

${ }^{34}$ Abu al-Ula Muhammad bin Abd al-Rahman al-Mubarakfuri, Muqaddimah Tuhfah al-Ahwaziy bi Syarh Jami al-Turmuziy, juz VI (Beirut: Dar al-Fikr, 1979), h. 427

${ }^{35}$ Muhammad Abu Bakar al-Raziy, Mukhtar al-Sihhah (Beirut: Dar al-Fikr, 1991), h. 323
} 
Menghadapi realitas hidup seperti itu secara bijak Nabi saw menyeru bersabar. Muhammad Abu Bakar al-Raziy mengartikan sabar dengan menahan diri (nafsu) dari keluh kesah. ${ }^{36}$ Sedangkan Muhammad Farid Wajdi mendefinisikan dengan sikap meninggalkan keluhan atau pengaduan selain kepada Allah swt. ${ }^{37}$

Berdasar pada keterangan di atas, maka dipahami bahwa nepotisme sesuai dengan pengertiannya, bertujuan "mengawetkan" atau dalam batas-batas tertentu "memaksakan" kehendak dan kepentingan untuk "merajai" kekuasaan (politik) dan penguasaan ekonomi (bisnis), sehingga salah satu dampaknya adalah praktik monopoli yang didominasi oleh keluarga atau orang-orang dekat tertentu. Sehingga Nabi saw menyarankan agar menghadapi suasana demikian, haruslah disertai kesabaran.

\section{Klasifikasi Hadis}

Berdasarkan dari hasil takhrij yang telah dilakukan, maka hadishadis yang terkait dengan KKN dapat diklasifikasi sub temanya; jumlah mukharrij-nya dan jumlah hadisnya dengan perincian sebagai berikut:

1. Hadis tentang korupsi; dalam Shahih al-Bukhäri, 2 buah matan hadis ; Shahih Muslim, 2 buah matan hadis; Sunan Abu Dawud, 2 buah matan hadis; Sunan al-Nasa'i, 1 matan hadis; Musnad Ahmad bin Hanbal, 1 buah matan hadis. Dengan demikian, jumlah hadis-hadis tentang korupsi sebanyak 10 matan hadis dan hadis-hadis tersebut terdapat dalam 6 kitab rujukan hadis

2. Hadis tentang kulusi; dalam Sunan Turmuzi 2 matan; Sunan Abu Dawud 1 matan hadis; Sunan Ibn Majah, 1 matan hadis; Musnad Ahmad bin Hanbal, 4 matan hadis; dan dalam Mustadrak alHakim, 3 matan hadis. Dengan demikian, jumlah hadis-hadis

\footnotetext{
${ }^{36}$ Muhammad Farid Wajdi, Dairah al-Ma'arif al-Qarn al-Isyrin, jilid V (Beirut: Dar al-Fikr, 1979), h. 105

${ }^{37}$ Al-Nawawy, Shahih Muslim bi Syarh al-Nawawi (Beirut: Dar al-Kutub al-Ilmiyah, 1994), h. 546
} 
tentang korupsi sebanyak 10 matan hadis dan hadis-hadis tersebut terdapat dalam 5 kitab rujukan hadis.

3. Hadis tentang nepotisme; dalam dalam Shahih Bukhari 3 matan hadis; Shahih Muslim, 2 matan hadis; Sunan al-Turmuzi 1 matan hadis; Sunan Nasa'i, 1 matan hadis; dan Musnad Ahmad 2 matan hadis dan dalam Mustadrak al-Hakim, 2 matan hadis. Dengan demikian, jumlah hadis-hadis tentang nepotisme sebanyak 11 matan hadis dan hadis-hadis tersebut terdapat dalam 6 kitab rujukan hadis.

Berdasarkan klasifikasi di atas, maka diketahui bahwa hadis-hadis tentang KKN keseluruhannya berjumlah 31 matan hadis. Hadis-hadis tentang KKN yang telah di-takhrij dan diklasifikasi tersebut, kelihatannya memiliki redaksi matan yang berbeda antara satu dengan yang lainnya, sehingga dapat dikatakan bahwa hadis-hadis tentang KKN diriwayatkan secara maknawi. Sebagian hadis-hadis tentang KKN tersebut dikutip dalam bahasan selanjutnya untuk dianalisis secara tematik (syarh al-hadis bi al-mawdhu'iy), sebagian lagi akan dikutip dalam bentuk lampiran.

\section{Asbab al-Wurud Hadis-Hadis KKN}

Sesuai hasil penelusuran penulis dalam berbagai kitab rujukan, ternyata hadis-hadis tentang korupsi tidak ditemukan secara eksplisit sabab wurud-nya, namun secara implisit dapat dipahami sabab wurudnya melalui matan hadisnya. Untuk hadis-hadis tentang kolusi, memang tidak ditemukan sabab wurud-nya secara eksplisit maupun implisit. Sedangkan hadis-hadis tentang nepotisme, ditemukan riwayat mengenai sabab wurud-nya, yakni; ketika ada ketentuan dari Allah swt (melalui Alquran) mengenai al-fay (harta rampasan perang), maka Rasulullah membagi al-fay tersebut seusai Perang Hunain pada orang-orang mu'allaf, dan orang-orang Anshar tidak mendapat pembagian al-fay. Padahal mereka (kaum Anshar) beranggapan akan memperoleh (al-fay) sebagaimana yang diperoleh orang-orang selainnya. Lalu Rasulullah berpidato dan berkata: Wahai orang-orang Anshar kamu dahulu dalam 
keadaan tersesat, lalu karena aku maka Allah memberi kalian petunjuk; kalian juga dahulu saling bercerai-berai, lalu karena aku maka Allah menjadikan kalian bersatu; kalian juga dahulu hidup dalam keadaan papa, lalu karena aku maka Allah menjadikan berkecukupan. Setiap Rasul mengucapkan sesuatu, mereka (kaum Anshar) menyatakan: Allah dan Rasul-Nya lebih mengetahui. Kemudian Rasululullah bersabda; apa yang menghalangi kalian untuk menjawab: Allah dan Rasul-Nya lebih mengetahui Lebih lanjut Rasulullah saw bersabda: apakah kalian merelakan manusia pergi dengan membawa kambingnya atau dombanya dan kamu (juga rela) pergi bersama Rasulullah saw ke suatu tempat dan sekiranya bukan hijrah maka kalian tidak menjadi orang-orang Anshar; sekiranya pula manusia melewati sebuah lembah atau bangsa, maka akan melaui lembahnya Anshar dan bangsa Anshar yang menggunakan pakaian dalam untuk berselimut. Lalu Nabi saw menyabdakan hadis 38 ستلقون بعدى أثرة فاصبرو حتى تلفونى اللحوضز

\section{Penutup}

Berdasar pada uraian-uraian terdahulu, maka dapat dirumuskan beberapa kesimpulan, sebagai berikut:

1. Perlu digaris bawahi bahwa tujuan penetapan hukum dalam Islam, termasuk larangan KKN adalah untuk memelihara kemas-lahatan sekaligus menghindari mafsadat. Ada lima unsur pokok yang harus dipelihara dan diwujudkan dalam rangka menegakkan tujuan hukum Islam, yaitu memelihara agama, jiwa, akal, keturunan dan harta.

2. Pemberian hadiah kepada pejabat yang tidak sedang melaksanakan tugasnya dibolehkan, sepanjang hadiah tersebut tidak akan mempengaruhinya untuk melakukan tindakan penyelewengan.

3. Seruan Nabi untuk bersabar menyikapi sikap nepotisme penguasa, dimaksudkan agar sendi-sendi kehidupan umat senantiasa

\footnotetext{
${ }^{38}$ Jalāl al-Dīn al-Suyūtiy, Asbāb al-Wurūd al-Hadìś (Cet.I; Bairūt: Dār al-Maktab al-Ilmiyah, 1984), h. 226
} 
tetap terpelihara dengan baik. Patut diyakini bahwa Nabi di sini secara sadar dapat melihat berbagai kemungkinan negatif apabila sikap nepotisme tersebut disikapi pula secara keras dan frontal.

Sesuai dengan rumusan kesimpulan di atas, maka disarankan kepada segenap pihak, khususnya para pejabat negara dan masyarakatnya agar senantiasa menghindarkan diri dari sikap dan praktek-praktek KKN, karena prilaku seperti ini, bertentangan dengan esensi agama.

\section{Daitar Pustaka}

\section{Al-Quran al-Karim}

Al-Ahadis min al-Kutub al-Tis'ah wa Mustadrak al-Hakim

Abu Zahrah, Muhammad, Ushul al-Fiqh (mesir: Dar al-Fikr al-Arabiy, 1985

Al-Asqlani, Ibn Hajar. Fath al-Bariy bi Syarh Shahih al-Bukhari, juz VII dan juz XV; t.tp.: Dar al-Fikr wa Maktabah al-Salafiyah, t.th

Al-'Ayniy, Badr al-Din Abu Muhammad bin Ahmad. Umdah al-Qari' Syarh Shahih al-Bukhari, jilid VIII. Beirut: Muhammad Amin Damaj, t.th

Al-Darainiy, Fathi. al-Manhaj al-Ushuliyah fiy al-Ijtihad bi Ra'yi fi alTasyri'. Damysiq: Dar al-Kitab al-Hadis, 1975

Departemen Pendidikan dan Kebudayaan, Kamus Besar Bahasa Indonesia. Jakarta: Balai Pustaka, 2000

Fara'i, Abu Ya'la Muhammad bin Husain. Al-Ahkam al-Sultaniyah. Bairut: Dar al-Islamiyah, $1408 \mathrm{H}$

Ismail, M. Syuhudi. Metodologi Penelitian Hadis Nabi. Cet. II; Jakarta: Bulan Bintang, 1992 
Al-Jauziyah, Ibn Qayyim dan Abii al-Tayyib, 'Awn al-Ma'bud Syarh Sunan Abi Dawud, juz VIII. Beirut: Dar al-Fikr, t.th

Al-Jurjani, Ali bin Muhammad. Kitab al-Ta'rifat. Jeddah: al-Haramain, t.th

Klitgaard, Robert. Controlling Corruption, diterjemahkan oleh Hermoyo dengan judul Membasmi Korupsi, Ed. 2. Cet. II: Jakarta Yayasan Obor Indonesia, 2001.

Ma'luf, Louis. Al-Munjid fi al-Lughah, jilid I. Cet. XXXII; Bairut: Dar alMasyriq, 1992

Al-Mubarakfuri, Abu al-Ula Muhammad bin Abd al-Rahman. Muqaddimah Tuhfah al-Ahwaziy bi Syarh Jami al-Turmuziy, juz VI. Beirut: Dar al-Fikr, 1979.

Al-Nawawy, Shahih Muslim bi Syarh al-Nawawi. Beirut: Dar al-Kutub al-Ilmiyah, 1994

Al-Raziy, Muhammad Abu Bakar. Mukhtar al-Sihhah. Beirut: Dar alFikr, 1991

Al-San'ani, al-Kahlani, Muhammad bin Ismail. Subul al-Salam, juz III dan IV Indonesia: Maktabah Dahlan, t.th

Shihab, M. Quraish. Lentera Hati Kisah dan Hikmah Kehidupan. Cet. XIII; Bandung, 1998

al-Suyūtiy, Jalāl al-Dīn Abd. al-Rahman. Jāmi' al-Shagìr fī Ahādìśs alBasyìr al-Nazīr jilid I; Kairo: Dār al-Kutub al-Arab, 1967. . Asbāb al-Wurūd al-Hadīś. Cet.I; Bairūt: Dār al-Maktab al-Ilmiyah, 1984.

Al-Syaukani, Nail al-Awthar, juz IX. Bairut: Dar al-Fikr, t.th

Wajdi, Muhammad Farid. Dairah al-Ma'arif al-Qarn al-Isyrin, jilid V. Beirut: Dar al-Fikr, 1979.

Wensinck, A. J. al-Mu'jam al-Mufahras li Alfazh al-Hadiz al-Nabawiyah, juz IV. Leiden : E.J. Brill, 1969 